\title{
Transformasie, partisipasie en pluraliteit - die Kappadosiese erfenis vir die Sistematiese Teologie in die derde millennium
}

Author:

Tanya van Wyk $^{1}$

Affiliation:

${ }^{1}$ Department of Systematic Theology and Christian

Ethics, University of Pretoria South Africa

\section{Correspondence to:}

Tanya van Wyk

Email:

tanya.vanwyk@up.ac.za

Postal address:

Private Bag X20, Hatfield

0028, Pretoria, South Africa

Dates:

Received: 29 July 2013

Accepted: 30 July 2013

Published: 25 Sept. 2013

How to cite this article:

Van Wyk, T., 2013,

'Transformasie, partisipasie en pluraliteit - die

Kappadosiese erfenis vir

die Sistematiese Teologie

in die derde millennium',

HTS Teologiese Studies/

Theological Studies 69(1),

Art. \#2040, 9 pages.

http://dx.doi.org/10.4102/

hts.v69i1.2040

\section{Copyright:}

(C) 2013. The Authors.

Licensee: AOSIS

OpenJournals. This work

is licensed under the

Creative Commons

Attribution License.
Read online:
Transformation, participation and plurality: The Cappadocian heritage for Systematic Theology in the third millennium. The aim of this article is to demonstrate how Systematic Theology in the third millennium utilises facets from the legacy of the Cappadocian fathers. The focal point is the influence on present-day Trinitarian theology. Aspects which are discussed include matters of metaphysics, philosophy, morality and spirituality. The influence of the legacy of the Cappadocian fathers concerns the challenge which diversity and plurality create in systematic theology. This legacy is explored by means of the 'lived experiences' of the life stories of the Cappadocians. These narratives illustrate a shift from the 'impersonal' to the 'personal', from 'disengaged abstraction' to 'relational participation'. The latter is referred to as 'a pastoral doctrine of the Trinity' by Paul S. Fiddes. The emphasis on 'economical ontology' confirms the Cappadocians' relevance for a present-day ethical discourse and the 'aesthetics of a feeling for the Other'.

\section{Die belang van die Kappadosiese erfenis}

Dit was eers gedurende die twintigste eeu dat verskeie dissiplines van die teologie en loci van die Sistematiese Teologie, asook die sosiale wetenskappe in die algemeen, begin het om ryklik van aspekte van die klassieke Triniteitsleer gebruik te maak (O’Donnel 1988:5-34; kyk ook na Grenz 2001:25-27). Die doel hiervan is om te reflekteer oor sake wat wissel van metafisika in die filosofie tot moraliteit en spiritualiteit in die teologie (O'Collins 1999:1-25; kyk ook na Bryant 1990:4-20). Waarskynlik is die belang van nadenke oor die verskynsel 'pluraliteit' een van die belangrikste stimulerende faktore (kyk na Migliore 2004:145). Die Suid-Afrikaanse sistematiese teoloog Rian Venter (2011:3) praat van 'n 'Trinitariese renaissance' en gebruik'n uitdrukking soos die 'herontdekking van Trinitariese grammatika' wanneer hy na relevante teologie ('Speaking God today') verwys. Venter (2011:2, voetnota 4) meen dat die werke van Kärkkäinen (2004), Callen (2004) en Shults $(2005,2006)$ goeie oorsigte bied om te demonstreer dat theologies of the Other - met foci op aspekte soos sosiale klas, ras, kultuur en geslagtelikheid (gender) - die vooronderstelling vorm van die uitspraak deur Alain Badiou ([2005] 2007:166) in sy oorsig oor die twintigste eeu dat 'die God van monoteïsmes' dood is. ${ }^{1}$ Dit is teen hierdie agtergrond dat die werke van Harvey Cox (1999), 'The myth of the twentieth century: The rise and fall of "secularization"' en Richard Kearney (2010), Anatheism: Returning to God after God, 'n dekade later, die relatiewe waarde van die Christendom gedurende die twintigste eeu illustreer.

Venter se student, Jaco de Witt (2008:16-17), reken dat daar twee redes vir die nuwe belangstelling in Trinitariese denke is. Eerstens bring die toenemende bewussyn van die rol wat pluraliteit in die sosiale wetenskappe speel mee dat daar van teoloë verwag word om baie spesifiek oor Christelike identiteit en die betekenis van ' $n$ 'Christelike lewe' in die samelewing te kommunikeer. Hy formuleer dit soos volg: 'This search to achieve a better articulation about the Christian God led to the re-evaluation of the way we have viewed and conversed about the Trinity in the past' (De Witt 2008:17). Tweedens vereis postmoderniteit van 'God-talk' persoonlike taal wat vandag se realiteite met legitimiteit in dinamies-sosiale en relasionele terme in berekening bring. De Witt (2008:17) verwys na Cunningham (2003:189) wat meen dat postmoderniteit die konteks skep waarbinne elemente van Trinitariese teologie singewing bied. Venter maak die 'Trinitariese renaissance' in die Sistematiese Teologie van toepassing op die uitdagings van postmoderne kerk-wees in

1.Badiou ([2005] 2007) fokus op 75 jaar van die twintigste in 1917 en eindig met die verbrokkeling van die VSSR en die beëindiging van die koue oorlog. In sy kritiek op totalitarisme as meesternarratief propageer hy kontranarratiewe wat nie op beide sowel logika en as dialektiek as epistemologie gebaseer is nie en meesternarratief propageer hy kontranarratiewe wat nie op beide sowel logika en as dialektiek as epistemologie gebaseer is nie en
wil hy 'formalized inhumanism' as die vervanging van 'animal humanism' beskou. In die tydskrif, The philosophy of the social sciences, begin Andrew Koch (2009:119) sy oorsigartikel oor Alain Badiou se boek oor die twintigste eeu met die volgende opmerkings: 'The twentieth century was a century of terror, destruction, and acts of barbarism on a scale never before witnessed in human history. The century began with Herculean acts of genius and the potential to transform the world into something just shy of paradise. Human beings were in charge. God was dead, and for the first time in human history mankind was unleashed from the shackles of superstition and "ignorance." Alain Badiou's book, The Century, concerns the question of what happened to derail the Enlightenment, Humanism, and all the promise of a Prometheus that was now unchained. 
veranderende demografiese omstandighede soos formele en informele verstedeliking. Aspekte van die nuwe middestad en plakkersdorp-omstandighede, met dié se gepaardgaande sosiale impakfaktore, bring mee dat die kombinasie tussen 'relasionele Trinitariese' en 'postmoderne ekklesiologiese' denke besonder relevant en aktueel geword het. Vir hierdie doel lê Venter (2006:201-224) 'n verband tussen 'n 'Trinitariese ekklesiologie' en 'n 'filosofie van ruimte'.

Onafhanklik van Venter se bydrae - hoewel van agterna beskou, in sterk aansluiting by sy denke en uitgaande van die bewussyn van pluraliteit - word daar hier op die ekklēsia as ruimte gefokus. In plaas daarvan om in algemene terme van 'n 'Trinitariese renaissance' te praat, word daar om bepaalde redes dus hier eerder in besondere terme na 'n 'Kappadosiese renaissance' verwys. Die basiese rede waarom die Kappadosiërs se erfenis van belang is wanneer te midde van komplekse plurale omstandighede op verhoudinge in die postmoderne ekklēsia gefokus word, is geleë in die vroegste 'apostoliese kerk' waar verskeidenheid in kerk-wees en die dinamiek van die één Heilige Gees onlosmaaklik aan mekaar verbind was:

Net soos die liggaam 'n eenheid is en baie lede het, en soos al die lede saam, al is hulle baie, een liggaam vorm, so is dit ook met die liggaam van Christus. Omdat ons almal een liggaam geword het, is ons almal met die een Gees gedoop, of ons nou Jood of Griek is, slaaf of vry. Ons is almal van die een Gees deurdrenk. (1 Kor 12:12-13)

In hedendaagse sistematies-teologiese taal verwoord, word Paulus se 'koördinasie van relasies' soos volg in Otto Weber se weergawe van Karl Barth se ekklesiologie teruggevind (gedeeltes in aanhalingstekens en kursief is oorspronklike woorde en beklemtoning van Barth self in sy Kirchliche Dogmatik, Band IV, 3/2):

DieGemeinde ist in Christus! Und damit ist die 'Gnadenordnung', in der sie steht, zugleich eine 'Seinsordnung' ... 'Der Heilige Geist ist die macht, und seine Aktion ist das Werk der Koordination des Seins Jesu Christi und des von ihm verschiedenen, aber in ihm eingeschlossenen Seins seiner Gemeinde' ... Der Heilige Geist ist die Macht des Geschehens dessen, was Jesus Christus, unvertretbar und in absolute eigener Vollmacht, gewirkt hat. Nur im Heiligen Geist hat es aktuelle Geltung, daß das Sein der Gemeinde 'ein Prädikat, eine Dimension' des Seins Jesu Christi selber ist. Die christologische Begründung der Gemeinde ist ihre pneumatologische Wirklichkeit! (Weber [1963] 1967a:319)

Sowel die beklemtoning van die relasionele koördinasie tussen Vader, Seun en Gees as die ontiese verband tussen Sein en Aktion is sprekend van die erfenis van die Kappadosiese kerkvaders.

In die lig van hierdie erfenis wat ook by Schleiermacher (in die negentiende eeu) en by Barth (in die twintigste eeu) terug te vind is, is dit vir die doeleindes van hierdie artikel nie werklik van belang dat Schleiermacher sy 'geloofsleer' op versweë wyse met die Triniteitsleer as die oorkoepelende vooronderstelling van sy totale geloofsleer afsluit en dat Barth, anders as Schleiermacher, sy Kirchliche Dogmatik eksplisiet met die Triniteitsleer (KD 2/1, in Weber ([1963] 1967b), voortspruitend uit sy Skrifbeskouing (KD 1/1 in
Weber ([1963] 1967b:11-21), begin en met die ekklesiologie (KD 4/3, in Weber ([1963] 1967b) afsluit nie (kyk na Schüssler Fiorenza, in Mariña 2005:171-188). Teenoor 'n moderne teoloog soos Robert W. Jenson (1982) en 'n teoloog uit Schleiermacher se eie tyd, Johann A. Möhler ([1827] 1996:5, 430), het Richard R. Niebuhr (1964:156), Wolfhart Pannenberg (1991) en Jürgen Moltmann ([1980] 1981) (kyk na die vergelyking tussen Pannenberg en Moltmann deur Muhrmann-Kahl 1997:165-225) nie die opinie gedeel dat Schleiermacher geen verband tussen kerk-wees en gelowigwees en die klassieke Kappadosiese Triniteitsleer lê nie. Hoewel laasgenoemde teoloë hulle eie onderskeie nuanses en selfs kritiek op mekaar gehad het, het hulle almal ingesien dat Schleiermacher - as gevolg van sy diepgaande beïnvloeding deur die Kantiaanse onderskeid tussen praktiese, teoretiese en estetiese rasionaliteit - uiters versigtig was om op onverantwoordbare wyse antropomorfies oor God te praat, en daarom die versweë vooronderstelling van die oorkoepelende plek van die Goddelike Drie-enigheid in Schleiermacher ([1830] 1928) se geloofsleer. Niebuhr (1964) stel dit soos volg:

Consequently, the doctrine properly belongs at the conclusion of [Schleiermacher's (1830) 1928] The Christian Faith, for its authentic content is nothing else than the body of the theological exposition of the whole of the faith. (bl. 156, vgl. Schüssler Fiorenza 2005:172)

Weliswaar het ook Möhler ([1827] 1996:79-205) ingesien dat daar in Schleiermacher se teologie 'n noue verband tussen die siening oor die eenheid van die kerk en dié oor die eenheid in die Triniteit bestaan, maar hy het op grond van Schleiermacher ([1822] 1835) se vergelyking tussen Sabellius en Athanasius hom van 'Sabelliaanse modalisme' verdink. ${ }^{2}$ Nóg Pannenberg nóg Moltmann deel hierdie kritiek. Schleiermacher se aansluiting by die Kappadosiese kerkvaders is veral duidelik in sy historiese Jesus-lesings wat op die proloog in die Johannes-evangelie gebaseer is (kyk na Schleiermacher [1832] 1864).

In die volgende opmerkings van Schüssler Fiorenza word die genuanseerdheid van hierdie teoloë verwoord. Dit blyk uit die invloed van die Kappadosiese erfenis wat in die beklemtoonde deel duidelik te sien is, te wete die verband tussen Sein en Aktion, oftewel tussen ontologiese Triniteit en ontiese relasies wat die etiek van kerk-wees raak:

Although Pannenberg's starting point, which is the relation of Jesus to the Father, is closer to Schleiermacher's Christological starting point, nevertheless his conclusion is quite different in the way he moves from the relation of Jesus to the Father to intratrinitarian mutuality. Hence he notes: 'we see a mutuality in their relationship that we do not see in the begetting' [Pannenberg 1991:313]. Although Moltmann likewise [kyk na Muhrmann-Kahl 1997:165-225] begins from a Christological starting point, he underscores the threeness so much that Walter Kasper [1984:379, voetnota 183] discovers the danger of a tendency toward tritheism. These authors represent a conception of the Trinity opposed to Schleiermacher, although they have been influenced

2.Sabellius van Pentapolis (Libië), circa 215 n.C. (kyk na Rush 1980:10; Moreschini \& Norelli 2005b:337-338), het volgens Tertullianus, circa 160-220 n.C., in sy Adversus Norelli 2005b:337-338), het volgens Tertullianus, circa 160-220 n.C., in sy Adversus
Praxean (vgl. Lossky 1957:58; Meyerdorff 1974:181) geen onderskeid tussen Vader en Seun in die Triniteit, soos deur Kappadosiërs geleer, getref nie. 
by his starting point and his attempt to link the economy of salvation with the immanent Trinity. (Schüssler Fiorenza 2005:185)

Die erfenis wat die Kappadosiese kerkvaders, veral dié van Eunomius van Cyricus en Gregorius van Nyssa (kyk na Schüssler Fiorenza 2005:187, eindnota 17), wat op bogenoemde teoloë invloed uitgeoefen en gelei het tot wat vandag as die 'sosiale Trinitariese ekklesiologie' bekendstaan, sal vervolgens in ' $n$ kort narratief oor die Kappadosiërs beskryf word. Hierdie narratief sal met 'n terminologiese opheldering voorafgegaan word. Die bedoeling van die oorsigtelike narratief is nie om die kompleksiteit van die 'Trinitariese denke' te ontleed, krities te beskryf en die nuanses onder die verskillende verteenwoordigers uit te lig nie. Die bedoeling van die narratief is bloot om die kerklike konteks waarbinne hierdie erfenis ontstaan het duideliker reliëf te gee. Daarom word daar in die artikel, wat sowel die begripsmateriaal as die lewensomstandighede van die belangrikste Kappadosiërs betref, op inligting vanuit sekondêre bronne voortgebou.

\section{Die Kappadosiese narratief Terminologiese verheldering}

Tydens die konsilie van Aleksandrië (362 n.C.) is die Griekse woord hupostasis formeel as ekwivalent van die Latynse persona gebruik en kry die Kappadosiërs se Griekse formule vir die Triniteit, mia ousia, treis hupostaseis, formeel erkenning. Volgens Engelbrecht (1978:138) ${ }^{3}$ was dit die oortuiging van sowel Calvyn as Melanchton dat die Kappadosiërs se oudkerklike terme vir die Triniteit dogmaties onvervangbaar is, te wete in Grieks mia ousia, treis hypostaseis [een wese, drie persone] en in Latyn una substantia, tres personae. Die belydenis dat die Seun homoousios, consubstantia [eenswesens] met die Vader is, is op verskillende wyses deur drie terme, naamlik 'eenswese', 'Triniteit' en 'persone' weergegee. 'Wese' verwys ook na phusis, natura en essentia. 'Persoon' weer verwys ook na subsistentia en prosopon, terwyl 'Triniteit' ook na Trinitas en proprietas verwys. Die Reformatore het hulle deur die gebruik van hierdie terme teen die Arianisme en Sabellianisme afgegrens (Engelbrecht 1978:139). In afgrensing teen Sabellius het die Latynsprekende kerk die term persona bo die Griekse woord prosopon gekies (vgl. Bethune-Baker 1903:105, 234-235). Die term homoousios is in Latyn vertaal met consubstantia en ousia met substantia. Verwarring het egter ontstaan aangesien substantia juridies ook kan verwys na die eiendomlike wese wat al drie persone gemeenskaplik besit (Bethune-Baker 1903:235). Dit kan verder ook verwys na spesifieke eiendom wat deur 'n persoon besit word en wat dié persoon van ander persone onderskei. Substantia dui dan op 'n distinctio, 'n onderskeid in die sin van die regsterm species ('n spesifieke item word gekoop, nie 'n willekeurige een uit 'n soortgelyke groep nie). Hilarius van Poitiers (in Moreschini \& Norelli 2005a:258-260; kyk ook na Meijering \& Van Winden 1982) het substantia gebruik om na die drie onderskeie persone in die Drie-eenheid te verwys, naamlik

3. Hierdie oorsig is gebaseer op B.J. Engelbrecht (1978) wat weer gebruik gemaak het van die paradigmatiese indeling in Théodor de Regnon (1892) se Études de théologie positive sur la Sainte Trinité. dat daar drie substansies in God is (Calvyn [1559] [1931] 1956:102-105). ${ }^{4}$ Dionisius Romanus (Epistula ad Dionysium Alexandrinum) het ousia en hypostasis identies gebruik en Dionisius Aleksandrinus (kyk na The divine names 4.1: 709B, in Moreschini \& Norelli 2005a:668-670) het die terme gebruik om tussen 'wese' en 'persoon' te onderskei. Origines het nie tussen die Griekse terme ousia, hupostasis, hupokeimenon en prosopon onderskei nie. Athanasius (in De sancta trinitate 1970:80-126, 307-334) het die terme theotēs [goddelikheid], ousia [wese], hupostasis [persoon], idiotes tēs ousias [eintlikheid van die syn], oikeiotēs tēs hupostaseōs [eiendomlikheid van die hupostasis] identies gebruik. Hierdie terme is gebruik om die essensiële teenoor die toevallige eienskappe te verwoord. Dit gaan egter nie om die somtotaal van die eienskappe nie, maar om die aspekte wat onderliggend aan daardie eienskappe is. Volgens Athanasius is die 'persoon' (hupostasis) gelyk aan die 'wese' (ousia). Alle betekenis van die persoon ís die syn self (auto to on). Athanasius het hupostasis en ousia [persoon en wese] volkome gelykgestel en dit weer gelykgestel aan theotess [goddelikheid] (vgl. Von Harnack 1888:215).

Die term phusis [natuur] het aanvanklik dieselfde referensiële betekenis as ousia en essentia gehad, naamlik 'wese'. Dit was die kerkvaders Athanasius en Tertullianus wat die 'terme' in die debat oor die tweenature-leer nader gekwalifiseer het. Tertullianus (De testimonio anima 32; kyk na Moreschini \& Norelli 2005b:325-326) tref die onderskeid tussen substansie en die aard van substansie (aliud est substantia, aliud natura substantiae). So is mense en diere dieselfde natura, maar nie dieselfde substantia nie. Wanneer daar oor God gesê word dat God 'n eie substantia het, dui dit op God se unieke substantia. Dit wil sê, geen ander wese het dieselfde substantia as God nie. Wanneer gesê word dat Jesus die substantia van God het, word bely dat Jesus God is. Volgens Tertullianus se onderskeid het twee entiteite wat dieselfde substantia het nie noodwendig dieselfde natura (phusis) nie. Natura is volgens Tertullianus die somtotaal van 'n entiteit se eienskappe, terwyl die substantia die eienskappe dra. Substantia is die essensie, die eintlike wese, die eintlike syn. In Tertullianus se uiteensetting van sy verstaan van die tweenature-leer, gebruik hy dus eerder die term substantiae as naturae. Volgens hom sou die gebruik van die natura met betrekking tot Jesus daarop neerkom dat Jesus die eienskappe van God en mens besit, maar dat Jesus nie wesenlik God en mens is nie. Vir Tertullianus (kyk na Von Harnack 1888:300) is substantia histories swaar belaai en natura is ontoereikend. Dus het hy die term 'status' verkies en het hy gestel: Videmus duplicem statum, non confusum, sed conjunctum in una persona, deum et hominem Jesum ['n dubbele status, nie vermeng nie, maar saamgevoeg in één persoon, God en mens Jesus] (Von Harnack 1888:300; vgl. BethuneBaker 1903:139-140). 'n Soortgelyke standpunt word by Athanasius aangetref (Von Harnack 1888:235). Die phusis is die kompleks van eienskappe wat by ousia hoort, maar ousia 'dra' eienskappe en verwys (in Aristoteliese sin) na essensiële ('eintlike') wese. Die Seun is aan die Vader gelyk (homoiōsis tou huiou pros ton patera kata tēn ousian kai kata tēn phusin), dit wil sê na wese en na natuur.

4. Hillarius (De Trinitate I.iii): 'nos filii Dei sumus, sed non talis hic filius. Hic enim verus et proprius est filius origine, non adoptione, veritate, non nuncuptaione, nativitate,
non creatione.' Engelbrecht se verwysing na Hilarius kom uit Calvyn (Institusie I, 13, non creatione.' Engelbrecht se verwysin
5) (vgl. Meijering \& Van Winden 1982). 
Vanweë die aanvanklike identifikasie van phusis met ousia was dit vir die Griekssprekende gedeelte van die kerk nie problematies om van die goddelike en menslike phuseis [nature] van Jesus Christus te praat nie. Tertullianus se onderskeid het egter ' $n$ bepalende invloed op die teologie van die Latynssprekende gedeelte van die kerk uitgeoefen. Hierdie gedeelte van die kerk het die terme substantia en essentia bo natura verkies. Pous Leo het in die 30ste Epistola Dogmatica (in Wiles \& Yarnold 2011:587) die Triniteit as utraque natura beskryf, maar het et substantia daarby gevoeg. Heremitus Vincentius (in Kelly 2002:113) het die tweenatureleer beskryf deur die meervoudsvorm substantiae te gebruik: modus uniti substantiae en modus informantis substantiae. Hy het Nestorius daarvan beskuldig dat laasgenoemde persona en substantia verwar het en gevolglik geargumenteer het dat Jesus Christus twee personae gehad het (divina et humana) (kyk na Moreschini \& Norelli 2005b:566-571). Hierdie verwysingsraamwerk word by die konsilie van Chalcedon aangetref. Eers nadat die konsilie gesê het dat daar twee substantiae in Christus is, is daar gesê dat daar in Christus se persoon twee naturae is. Hier is probeer om natura (phusis) met die oorspronklike betekenisgebruik in lyn te bring, waar natura aan essentia, ousia en substantia gelyk is. In artikels 27-35 van die Geloofsbelydenis genoem na Athanasius word die substantia dus aangetref. Oor Christus word in terme van twee 'substansies' en nie van twee 'nature' nie gepraat. In Reformatoriese geloofsbelydenisse word natura (phusis) wel gebruik. In die Nederlandse Geloofsbelydenis word dit egter in Artikel 29 gebruik om substantia aan te dui (Engelbrecht 1978:143). In die Heidelbergse Kategismus ${ }^{5}$ word natura in Vraag en Antwoord 35 en 47 gebruik, en dan wel in die sin van natura humana. In hierdie belydenisgeskrif word daar nie na Christus se Godheid in terme van natura verwys nie, maar wel in terme van majestas et gratia. Hiermee word in die Heidelbergse Kategismus bely dat Jesus 'waaragtig God' is en dat Jesus die mens in alles benewens die sondige aard gelyk geword het (Van den Brink 1940:92-95).

Die term morphe (forma) is ook in sommige gevalle identies met ousia (substantia) gebruik. Die Latynssprekende gedeelte van die kerk se teësin in die gebruik van natura vanweë die ontoereikendheid daarvan (dit was dus nie beskrywend genoeg nie) het 'n vraag na ander beskrywende terme geskep. Bethune-Baker (1903:233) wys daarop dat Augustinus die uitdrukking filius Dei bo natura divina gebruik en in plaas van natura humana eerder filius hominis gebruik. Hilarius het forma Dei en forma servi gebruik om onderskeidelik na die goddelike en menslike natuur van Jesus te verwys. Hippolitos verwys na Paulus se woorde in Filippense 2:6, en morphe tou theo huparchōn, en aan die hand hiervan sê Hippolitos dat Jesus en ousia theo huparchón is. Tertullianus weer het morphé met status en conditio vertaal.

Hierdie oorsig deur Engelbrecht oor die terme in die Triniteitsleer help om die bedding daar te stel om die Kappadosiese narratief in konteks te verstaan. Die raamwerk van Frances M. Young en Andrew Teal ([1983] 2010:135-172) word gevolg om hierdie verhaal oorsigtelik weer te gee.

\section{Die drie Kappadosiërs: Basilides van Caesarea, Gregorius Naziansus en Gregorius van Nyssa}

Hierdie drie Kappadosiërs het 'n belangrike bydrae tot die formulering van die klassieke Triniteitsleer gemaak. Dit was egter nie die totale omvang van hulle dogmenhistoriese bydrae nie. 'n Uitstaande kenmerk van hulle werke was die rykdom van hulle geloofstaal, die gebruik van beelde en die wye aanvaarding van hulle insigte op die gebied van Bybelse, spirituele en dogmatiese tradisies. Dogmatiese tradisies het egter nie in hulle artikulasie daarvan versteen nie. Trouens, elkeen van hulle het 'n dinamiese en eie persoonlike en unieke bydrae tot die verwoording van die klassieke Triniteitsleer gelewer. Hulle blywende belang is geleë in aspekte van hulle werk, hoewel in hulle eie unieke situasies gebore, vir kerk-wees vandag relevant is. Dit geld veral die spanning tussen én die akkommodasie van geloof en kultuur teen die agtergrond van die opkoms en selfs die dominansie van die sogenaamde monastieke ideaal. Ten opsigte van beide hierdie sake het hierdie drie Kappadosiese kerkvaders 'n balans tussen twee uiterstes gevind. Dit het help voorkom dat die kerk as instelling enersyds heeltemal in die wêreld geabsorbeer is en andersyds heeltemal in ' $n$ woestyn van isolasie teruggetrek het.

Die lewe en werk van die drie Kappadosiërs was nou verweef. Al drie was uit gevestigde Christelike families afkomstig. Een van Basilides en Gregorius se broers, Petrus, het ook 'n biskop geword en aan hulle ma en suster is later die 'status van heilige' toegeken. Basilides en Gregorius se vriend, Gregorius van Nazianzus, se pa was 'n biskop. Al drie van hulle het onder die invloed van toegewyde gelowiges grootgeword. Hulle het gepraat en geskryf vanuit die oortuiging van die geloofstradisie waarin hulle grootgeword het en wat ' $n$ beslissende invloed op hulle geloofsbeelde, taal en houdings uitgeoefen het. Elkeen het egter 'n verdere roeping uitgeleef wat verder strek as die godsdienstige konteks van waaruit hulle gekom het. Hierdie konteks was nie sonder 'n historiese verwysingsraamwerk nie. Hulle families het aan die hoër sosiale klasse van Kappadosië behoort (vgl. Van Dam 2002:13) en al drie is ten spyte van die Christelikheid van hulle konteks aan die wye samelewing blootgestel. Elkeen het 'n klassieke opleiding ontvang (Mitchell 1993:77-79; Sartre [2001] 2005:417). Basilides het in Caesarea (die hoofstad van Kappadosië), Konstantinopel en Athene studeer. Gregorius van Nazianzus het ook in Athene studeer, maar in plaas van Konstantinopel het hy eerder Aleksandrië gekies. Gregorius, broer van Basilides, het ook 'n klassieke opleiding ontvang, alhoewel nie so omvangryk soos sy broer nie.

In 370 n.C. is Eusebius dood en Basilides was sy vanselfsprekende opvolger, maar sy uiteindelike verkiesing as die biskop van Kappadosië en sy regeringstydperk was nie sonder probleme nie, en hy was in 'n magstryd gewikkel (McGuckin 2001a:79, 2001b). Hy het sy posisie probeer 
konsolideer deur mense in nuut geskepte politieke setels aan te stel. Gregorius Nazianzus word in een van hierdie setels aangestel, onderwyl Basilides se jonger broer Gregorius in die dorp Nyssa tot biskop verkies is. Die drie se verbintenis

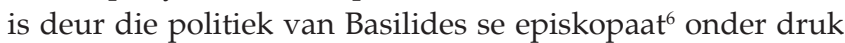
geplaas. In 'n tydperk waar 'n 'Arius-gesinde keiser' in beheer was (Young \& Teal [1983] 2010:139), was Basilides 'n sterk beskermer van die Niceense ortodoksie wat hom in konfrontasie met die keiser, Valentius, gebring het. Basilides se werk oor die Heilige Gees was 'a careful and limited gloss on the simple teaching of Nicaea' (Rousseau 1994:276).

Basilides is in 379 n.C. dood. Gregorius Nazianzus het daarvan te hore gekom terwyl hy self aan 'n siekbed gekluister was. Intussen het Theodosius keiser geword en Gregorius is as die vanselfsprekende biskop van Konstantinopel beskou, veral sodat die Niceense teologie prominensie kon geniet. $\mathrm{Na}$ Basilides se dood het sy mantel op sy broer Gregorius geval, wat baie gepubliseer het. Hy het sy broer se beklemtoning en verdediging van die Heilige Gees voortgesit. Teen 381 n.C. het Theodosius die Konsilie van Konstantinopel byeengeroep. Die twee Gregorii het saamgekom as verdedigers van die ortodoksie. Gregorius Nazianzus se verkiesing as biskop van Konstantinopel is bevestig, maar uit weersin teen die politiekery tussen die biskoppe tydens die konsilie het hy homself onttrek en geïsoleer. Hy het as biskop bedank en het sy verdediging van die ortodoksie met sy geskrifte voortgesit, veral aangesien die konsilie sy beklemtoning van die 'Goddelikheid' van die Heilige Gees verwerp het en toe 'n vae belydenisverklaring uitgereik het wat die homoousion nie bevat het nie. Hy het tot en met sy dood in 390 n.C. in Nazianzus gewoon en geskryf. Basilides se broer Gregorius was nie op hierdie manier geïsoleer nie en het gereeld vir die kerk, die politiek en die keiserlike sending in die Ooste gereis.

Gedurende hierdie tydperk het die opkoms en beklemtoning van 'n monastieke leefwyse spanning veroorsaak. Die monastieke beweging het'n konflik van ideale teweeggebring, naamlik tussen afsondering ter wille van kontemplasie en plig ten opsigte van die gemeenskap en leierskap. Gregorius Nazianzus se lewe en loopbaan getuig van hierdie spanning en dat hy soms in een van die rigtings ingetrek is (McGuckin 2001a:37-54). Basilides is nie deur hierdie spanning onaangeraak gelaat nie, maar het tog probeer om 'n balans tussen hierdie twee uiterstes van die tyd, naamlik publieke teologie of 'n asketiese leefwyse, te propageer (vgl. Torrance 2012:230). Hy het egter nie daarin geslaag om hierdie teoretiese balans uit te leef nie. Gregorius, sy broer, was klaarblyklik die suksesvolste in die integrasie van die twee opsies, soos blyk uit sy werk De Virginitate, waarin hy die selibaat bespreek hoewel hy getroud was (Gregorius Nyssenus [n.C. 335-395], De virginitate, in Silvas 2007:48-53). Dit was die drie Kappadosiërs se ideaal om balans tussen hierdie twee uiterstes teweeg te bring (Young \& Teal [1983]

6.Dit was'n gekompliseerde vriendskap. Basilides se geduld is beproef met die twee Gregoriusse se wangebruik van kerkfondse. Gregorius Naziansus het Basilides kwalik geneem omdat hy hulle jeugideaal van " $\mathrm{n}$ lewe van filosofie' verloën het en Gregorius, Basilides se broer, het ' $n$ minderwaardigheidskompleks ten opsigte van die ander twee gehad (kyk na Moreschini \& Norelli 2005b:86-89, 89-96).
2010:135). Die drie het 'n soortgelyke balanseringstoertjie in die oog gehad oor die vraag of die verhouding tussen die Christelike tradisie en die kontemporêre kultuur gespanne of akkommoderend behoort te wees. Hierdie ideaal van hulle hou verband met hulle eie teologiese oorspronge, wat teruggaan tot by Origines wie se toewyding aan die Skrif met sy interaksie met die Griekse filosofiese tradisie gepaardgegaan het (vgl. Rousseau 1994:4).

Ook Basilides se teologiese werke getuig van interaksie met die Griekse filosofie. Hy het voorbeelde van waardes en goeie filosofie by Homerus en Plato gekry en het die metodes en vrae van die filosowe as sy eie vooronderstellings aangewend. Hulle voorbeelde, illustrasies en voorstelle maak 'n groot gedeelte van sy geskrewe materiaal uit (kyk na Mitchell \& Young 2006:595). Tog het hy as 'offisiële verteenwoordiger van die ortodokse kerk' die filosowe en wetenskaplikes gekritiseer omdat hulle hulleself met vrae besig hou wat nie beantwoord kan word nie en dan oplossings vanuit hulle 'arrogante menslike rede' bedink. Terwyl hy dit egter doen, blyk sy eie kennis van die natuurwetenskap (veral die sterrekunde). Dit lyk asof Basilides 'n sintese tussen 'biblical teaching and selected elements of the profane systems' bereik het (Young \& Teal [1983] 2010:148).

Gregorius Nazianzus was in die besonder entoesiasties oor kulturele aangeleenthede. Dit was veral keiser Julianus se poging om Christene die reg tot onderrig en opleiding te ontneem wat Gregorius aangespoor het (vgl. Elm 2012:157). Hy neem sterk standpunt in teen aannames dat dinge soos die Griekse taal, wiskunde en digkuns 'heidens' sou wees en sy opinie was dat geen ras of nasie 'n eksklusiewe aanspraak op kultuur kon hê nie (kyk na Young \& Teal [1983] 2010:148). Gregorius het homself daarvoor beywer dat sulke 'intellektuele gereedskap' vir die opleiding van teoloë en die ontwikkeling van apologetiese argumente beskikbaar moes wees. 'n Groot gedeelte van sy Orationes (kyk na Asmus 1910:325-367) het hierdie oogmerk gehad. Ook Gregorius van Nyssa se werk, veral drie begrafnisredes wat hy in Konstantinopel gelewer het, vertoon oratoriese tegnieke van hoogstaande gehalte (Børtnes \& Hägg 2006:243-253). Gregorius was goed met die werke van Neoplatoniste, Plotinus en Lamblichus bekend en ook met die filosofiese tradisies van die Platonistiese skool in Athene (vgl. Turcescu 2005:50). Oor die eeue heen het die kerk en die kerk se boodskap in terme van die verwysingsraamwerk van die heersende konteks gestalte gekry. Mense het die Christelike tradisie deur die kulturele lense van hulle tyd geïnternaliseer (Young \& Teal [1983] 2010:151). Tegelyk het die kerk egter sigself van ander godsdienste gedistansieer. Hierdie dubbelkantige tradisie het ook die verwysingsraamwerk van die drie Kappadosiërs beïnvloed. Die ambivalente nuanse wat in die Kappadosiërs se werke teenwoordig is, reflekteer die opkoms van 'n 'verchristelikte kultuur' wat gebruik maak van nie-Christelike tradisies terwyl dit ook daarvan onderskei word.

Samevattend gesien, was al drie Kappadosiërs by die dogmatiese kontroversiële kwessies van hulle tyd betrokke 
en 'n groot gedeelte van hulle werk was op hierdie kwessies gerig. Die tydperk tussen 360 en 370 n.C. was 'n verwarrende tydperk waartydens talle alliansies gesmee is en politieke skuiwe plaasgevind het wat die teologie en die kerk beïnvloed het. Basilides het gepoog om 'n alliansie met Athanasius en die Westerse kerk te smee en daarmee 'n 'neo-Niceense' posisie te konsolideer (Young [1983] 2010:156). Hierdie posisie is deur sy broer en sy vriend verdedig, veral voor en na die Konsilie van Konstantinopel in 381 n.C. Alhoewel elkeen van die drie 'n unieke nuanse in hulle teologie verteenwoordig het, het hulle teologie sleuteldebatte beïnvloed wat vandag weer 'n renaissance beleef (Beeley 2008).

Die Kappadosiese erfenis is veral in die apologie teen Eunomius voortgesit. Hy het Aetius nagevolg en op die nie-vergelykbaarheid van die essensie van die Vader en die Seun aangedring. In 360 n.C. het Basilides probeer om die teologiese oortuigings van Eunomius te repudieer deur sy Apologia, getitel Contra Eunomium (in Hildebrand 2007:213). Hierdie apologetiese werk bestaan uit drie boeke. Die argument van die eerste boek is dat agennēsia [nie verwek] nie 'n essensiële eienskap van die Goddelikheid is nie. Die argumente in die ander twee boeke gaan oor die essensiële gelykheid van die Seun (boek 2) en die Heilige Gees (boek 3) met die Vader.

$\mathrm{Na}$ Basilides se dood het Gregorius Nazianzus die Eunomiaanse posisie in publieke redevoerings in Konstantinopel teëgestaan, terwyl Basilides se broer Gregorius op Eunomius se repliek op Basilides se Contra Eunomium gereageer het. Gregorius van Nyssa het verskeie korter traktate geskryf om die Heilige Gees se Goddelikheid te verdedig. Hy het die traktaat, Ad Ablabium [nie drie gode nie], na aan die einde van sy loopbaan geskryf (kyk na Coakley 2003; vgl. Barnes 2001; Turcescu 2005). Dit is hoofsaaklik as gevolg van hierdie traktate en die reaksies en teenreaksies daarop en die wedersydse laster en misleiding van die verskillende verteenwoordigers dat die fundamentele aspekte van die Trinitariese ortodoksie tot stand gekom het (vgl. Karfikova, Douglass \& Zachhuber 2007; Ludlow 2007).

Die kern van Eunomius se argument was sy aandrang daarop dat God 'kenbaar' is en volledig verstaanbaar is omdat God 'eenheid' is. God is nie verdeel of geskei in 'meer' nie en word ook nie soms een en soms ' $n$ ander nie, of verdeel van een ousia in 'n drievoudige hupostaseis nie, want God is altyd en absoluut een (Refutatio Confessionis Eunomii 33, in Moreschini \& Norelli 2005b:126-127). Eunomius argumenteer dat God se eenheid slegs moontlik is deur die verhewe en absolute Een van die tweede en die derde te isoleer. Om nie verwek te wees nie (agennēsia), is vir Eunomius die Goddelike attribuut wat God se eenvoud en uniekheid waarborg. Gregorius gebruik egter dieselfde beskrywing om te argumenteer dat 'n pluraliteit of hiërargie van 'geskeide wesens' onmoontlik is omdat een 'oneindigheid' nie groter of kleiner as ' $n$ ander 'oneindigheid' kan wees nie. Daar is drie 'subjekte', maar die drie se oneindigheid beteken dat hulle nie langs mekaar van mekaar onderskei kan word nie. Daar is 'eksistensie' en 'nie-eksistensie', maar daar is nie grade of prioriteite van 'syn' nie. Die kern van Gregorius se argument, soos sy broer Basilides s'n, is gemik teen die argument dat 'n hiërargie in 'Syn' of 'Wese' moontlik sal kan wees. Eunomius se poging om 'n onderskeid tussen God en die skepping daar te stel, het hom by 'n 'hiërargiese' verstaan van God se eksistensie uitgebring (vgl. Vaggione 2000:336-340). Gregorius het die onderskeid wat Eunomius tussen God en die skepping getref het as ' $n$ fundamentele werklikheid aanvaar, maar vir Gregorius is God 'n 'Trinitariese God'. 'Vader' en 'Seun' is nie verskillende 'wesens' nie, maar eerder 'n ewige verhouding binne een 'Goddelike Wese', want sonder die Seun het die Vader nie 'eksistensie' of 'naam' nie (Refutatio 6-7; Ad Ablabium 117, in Moreschini \& Norelli 2005b:126127). Aangesien Gregorius die ousia wat die Vader, Seun en Gees deel met behulp van die analogie in 'n generiese sin gedefinieer het, te wete ousia wat mense universeel deel (bv. Petrus, Johannes en Jakobus), is hy van tri-teïsme beskuldig (Contra Enomium I. 202, Gregorii Nysseni Opera 1-2, in Jaeger 1960). Hierbenewens het Gregorius ook die term 'generasie' gebruik en geargumenteer dat ook by mense en diere die 'generasie' van 'n kind-wees nie die 'substansie' van die vader verdeel of verminder nie. Dit is wel moontlik dat hierdie 'generasie' 'n aparte individu 'genereer' en gevolglik kan dit problematies wees om 'n monoteïstiese teologie op hierdie argument ten opsigte van gedeelde ousia te grond. Gregorius se definisie van 'goddelike syn' ('substansie') het egter hierdie problematiek ondervang. As 'goddelike substansie' in beginsel onverdeelbaar en ongedifferensieerd is en getal nie op 'goddelike eenvoud' van toepassing gemaak kan word nie, as 'een' en 'een' en 'een' nie saam getel kan word om 'drie' te maak nie, en as elkeen 'oneindig' is en nie in staat is om langs mekaar te bestaan nie, maar net in mekaar te bestaan, dan is die 'eenheid' van God per definisie verseker. As Goddelike substansie in beginsel onveranderlik is, dan is die wedersydse verhoudings binne die Triniteit (Godheid) ewig en nie-hiërargies (vgl. Beely 2008).

Die debat oor die Triniteitsleer het ook 'n debat oor die aard van teologiese taal veroorsaak (vgl. Maspero 2010:17-31). Eunomius het geargumenteer dat alle beskrywings van die 'Logos' analogies is en dat 'Seun van God' dus metafories en nie letterlik is nie. Gregorius weer het die analogiese aard van beskrywings en titels soos 'rots', 'deur', 'weg' en 'herder' aanvaar, maar het probeer om te onderskei tussen sulke beskrywings en ander wat op 'aard' betrekking het. Gregorius het dus gemeen dat 'Seun' meer letterlik as metafories te verstaan is (Contra Eunomium III, in Jaeger 1960:127141), aangesien hy gemeen het dat terme wat Christus se verhouding met die mensdom beskryf, analogies is. Terme wat egter Christus se verhouding met God beskryf, is essensieel. Gregorius het hiermee op die onverstaanbaarheid en onbegryplikheid van God aangedring. Daarom kan hy gekritiseer word vir sy pogings om enige iets oor God te probeer sê. Hy het erken dat alle name en beskrywende terme ontoereikend en menslik uitgedinkte uitdrukkings is. Hy meen egter dat al hierdie terme in die syn én die aksie van God gegrond is en dat sowel syn as aksie in die Bybel openbaar is. Volgens hom verleen dit 'n genoegsame basis om as grond vir teologiese konstruksie te dien. Hy benadruk egter dat al 
hierdie terme en beskrywings krities getoets moet word, want die afstand tussen Skepper en skepping is so wyd dat die terme tegelyk toepaslik en misleidend is. Daar is altyd die 'is-nie' aard van 'n metafoor en analogie; daar is altyd 'n verskil of 'n nie-gelykheid en dus het Gregorius gemeen dat Eunomius arrogant was om die 'wese/syn' van God te definieer en af te grens (Young \& Teal [1983] 2010:159).

Hierdie debat oor die Triniteitsleer het ook met die debat oor die Goddelikheid van die Heilige Gees gepaard gegaan. Basilides was ten gunste van die Goddelikheid van die Gees (vgl. een van sy traktate teen Enomius, Contra Eunomium III, in Jaeger 1960:110, 127-141). In 375 n.C. skryf hy sy De Spiritu Sancto as 'n verdere uiteensetting van sy argument (vgl. Anderson 1980 vir 'n Engelse vertaling van die teks). 'n Paar jaar later is Basilides se werk deur Ambrosius as basis vir die skryf van sy De Spiritu Sancto gebruik. Dit het ook as basis gedien vir die twee Gregorii se uiteensetting van Trinitariese teologie, al het Basilides nie na die homoousion van die Heilige Gees verwys nie (teenoor Gregorius Nazianzus) (Young \& Teal [1983] 2010:141). Na Basilides se dood in 379 n.C. het sy broer Gregorius die debat met hom oor die Heilige Gees verder gevoer. Met die debat het ook die Christologie in fokus gekom. Die dogmatiese probleme wat Arius geskep het, is deur die Kappadosiërs se Triniteitsleer vir die Ortodokse kerk bevredigend opgelos. Dit het wel ander vrae na vore gebring. Die transendensie van God wat voorheen 'n verhouding met die wêreld 'bemoeilik' het en waarin 'Logos' 'n mediasierol gespeel het, was nou nie meer 'n kwessie nie, aangesien 'Logos' die transendensie van God deelagtig was. In Basilides en Gregorius Nazianzus se Triniteitsleer (in reaksie op dié van Eunomius) wat heelwat op Apollinarius gesteun het, het hulle nie in hulle Christologie na ' twee seuns' verwys nie. Tog het hulle hulleself na die Konsilie van Konstantinopel in konflik met Apollinarius bevind. Gregorius Nazianzus se verklaring 'dit wat nie aangeneem word nie, kan nie verlos word nie', was gerig op Apollinarius se argument dat Christus nie 'n 'menslike siel' gehad het nie. Gregorius, broer van Basilides, het teenoor Apollinarius geargumenteer dat die 'menslike aard' in Christus herskep is en dat die verandering in Christus 'marks the beginning of the transformation in which each of us is called to participate' (Daley 2003:432-436).

\section{Die Kappadosiese erfenis se waarde vir'n teologie van 'die ander'}

Die twee begrippe transformasie en partisipasie vorm die epistemologiese kern van die Kappadosiese erfenis wat tot die resente beklemtoning van die belang van 'n 'Trinitariese ekklesiologie' gelei het - ten spyte van die 'akademiese' argument dat die Kappadosiese Triniteitsleer geheel abstrak en bloot 'antropologies' is, soos aangetref by sommige twintigste-eeuse denkers wat bygedra het tot die religiekritiese uitspraak dat die 'God van die monoteïsme' dood is. Ludwig Feuerbach ([1841] [1853] 2008:294), wat in sy religiekritiek op die 'antropologiese oorsprong' van die
Christelike geloof wys, haal Hillarius (De Trinitate I.iii, in Moreschini \& Norelli 2005b:258-260) vir hierdie doel aan. ${ }^{7}$

Dit is egter nie net bloot die opkoms van die verskynsel 'pluraliteit' in die derde millennium wat die epistemologiese belang van die begrippe 'transformasie' en 'partisipasie' vanuit die Kappadosiese fokus van syn én aksie in die ontologie of etiek nuwe sin gee nie (vgl. Migliore 2004:145; asook drie Suid-Afrikaanse sistematiese teoloë: Naudé 2007; Smit 2006:73-92; Venter 2004:207-239). ${ }^{8}$ Soos reeds gemeld, bring Venter (2011:2, voetnota 4) hierdie 'renaissance' in verband met die hedendaagse 'teologieë vir die Ander' en neem hy sosiale aspekte soos ras, kultuur en gender in ag.

Die konteks van ons tyd word deur Aleida Assmann, ${ }^{9}$ instemmend aangehaal deur Habermas, as 'n 'ko-evolusie van verwetenskapliking en sekularisasie' beskryf (Assmann 1993:61). Sy sien in dat kultuur (Bildung), wat sy as 'nationale Gedächteniskultur' beskryf (Assmann 1993, 2012a, 2012b; Von Geoffrey \& Assmann 2012), in die twintigste eeu verword het tot 'wetenskaplik geforseerde objekte met absolute godsdienstige waarde' (vgl. Habermas [1998] 2001:24). Karl Barth ([1924] 1925:125-155) het in 'n lesing op 26 September 1922 hierdie 'Synthese von Christentum und Kultur' as 'Das Problem der Ethik in der Gegenwart' beskryf. Karl Dienst (2012:22) verwys in sy resente werk 'Kirche mitten in der Stadt' hierna as die 'soziokulturelle Volkskirchenmilieu' (vgl. ook Dienst 2012:21, 45, 47). Dit is in reaksie op hierdie milieu dat menseregte universele geldigheid begin kry het. Habermas ([1998] 2001) beskryf egter dit wat tot dusver op hierdie gebied bereik is, as 'n gemaskerde (mask) skynheiligheid:

So-called equal rights may have only been gradually extended to oppressed, marginalized, and excluded groups. Only after tough political struggles have workers, women, Jews, Romanies, gays, and political refugees been recognized as 'human beings' with a claim to fully equal treatment. The important thing now is that the intellectual advances in emancipation reveal in hindsight the individual advances that human rights had fulfilled up to that times. That is, the egalitarian claim to universal validity and inclusion had also always served to mask the de facto unequal treatment of those who were silently excluded. (bl. 119-120)

Habermas is dus krities en ontmasker 'false universality', wat hy beskryf as die 'abstractive fallacy' van 'n Platonistiese 'Western notion of reason' met 'n 'imaginary humanity' wat nie

7.Hillarius, De Trinitate I.iii: 'nos filii Dei sumus, sed non talis hic filius. Hic enim verus et proprius est filius origine, non adoptione, veritate, non nuncuptaione, nativitate, non creatione.'

8.Naudé (2007:9) verwoord dit soos volg: 'Eenheid was nie net in die gemeentes van die NT' $n$ kernsaak nie. Dwarsdeur die geskiedenis was daar altyd weer tye waar eenheid in die kerk deur onderlinge verskille bedreig is. In die vierde eeu ná Christus toe die kerk'n raps oor die 300 jaar oud was, het ernstige leerverskille opgeduik. Dit het juis gegaan oor hoe God een kan wees. Dit het gelei tot ' $n$ groot en belangrike kerkvergadering, ' $n$ konsilie, in die dorp Nicea in die jaar 325. Dis later opgevolg me ' $n$ byeenkoms in Konstantinopel in 381 . En hier het die kerke besluit: Ons glo in een God, Vader, Seun en Gees, al het hulle wel onderskeie Persone, en al het Christus wel twee nature. Maar saam daarmee het hulle die merktekens van die kerk bely: Teenoor ons verskeurdheid, glo ons aan één kerk, wat staan op die leer van die apostels, en katoliek (algemeen) is.' Naudé (2007:9) sê eksplisiet dat hierdie eenheid meer as één kerklike denominasie raak.

9.Aleida Assmann is professor in Engels en literatuurwetenskap aan die Universität Konstanz. Sy het gepromoveer oor die 'legitimteit van fiksie' en haar huidige navorsing fokus op dimensies van die dinamiek van kulturele herinnering, toegepas op die vraag na die 'teenwoordigheid van die verlede in die hede'. Sy is die dogter van die Nuwe-Testamentikus Günther Bornkamm (student van Rudolf Bultmann) van die Nuwe-Testamentikus Günther Bornkamm (student van Rudolf Bultmann)
en is getroud met die Egiptoloog Jan Assmann. Kyk bronnelys vir publikasies asook en is getroud met die Egiptoloog Jan Assmann. Kyk
http://www.exc16.de/cms/assmann-aleida.html 
daarin slaag 'to provide every voice with a hearing' (Habermas [1998] 2001:120; beklemtoning oorspronklik). Vir hom lê die uitdaging in ' $\mathrm{n}$ demokratiese bestel wat tegelyk partikulier én universeel is. So 'n 'konstellasie' vereis waardes wat die dubbele spanning tussen inklusiwiteit-ekslusiwiteit en eenheid-verskeidenheid oplos. Hierdie waardes veronderstel partisipasie en transformasie, syn én aksie, sodat radikale insluiting nie maar net teoreties en abstrak verbeeldingryk bly sonder daadwerklike realisering nie. Vanuit 'n politieke perspektief beskou, meen Habermas [1998] 2001:73) dat demokrasie skynbaar die mees geskikte staatsregtelike model vandag is om op 'n selfkritiese wyse uit die katastrofes van die twintigste eeu te leer en die hedendaagse probleem van 'pluraliteit' in terme van menseregte op 'n menswaardige wyse aan te spreek. Dit sal egter insluiting sonder uitsluiting moet kan vooronderstel (Habermas 1996:154-184).

Mannion (2007) beskryf die 'church's task as a whole' en haal vir Rahner aan:

It is hoped that the church may become ever more truly a sacramental sign and mediation of the triune God who is love so that the church might demonstrate all the more vividly in its relations both ad intra and ad extra that Deus caritas est. (bl. xii)

Deur hierdie terminologie uit die Kappadosiërs se Triniteitsleer in die postmoderne konteks op die ekklesiologie van toepassing te maak, is die korrelasie tussen ontologie én etiek as die belangrikste vraagstelling vir kerk-wees aangedui. So beskou, is die kernprobleem van kerk-wees dat God se liefde nie in die kerk manifesteer nie, dit wil sê dat die belangrikste nota ecclesiae ${ }^{10}$ verloën word. Dit hou verband met die spanning tussen eenheid en verskeidenheid en die spanning tussen inklusiwiteit en eksklusiwiteit.

Die herwaardering van die Kappadosiërs se teologie wat in hulle lewensverhale weerspieël word, is die klem op persoon en nie net substansie nie. Dit is 'n verskuiwing van die on-persoonlike na die persoon-like, van onbetrokkenheid (abstraksie) na partisipasie en dui op, om die woorde van die sistematiese teoloog Paul S. Fiddes (2000) te leen, 'a pastoral doctrine of the Trinity'. Die Kappadosiërs se beklemtoning van 'ekonomie' naas 'immanensie' het die belang van die etiek sonder twyfel bevestig. Hulle laat vir die mensdom van die derde millennium die taal en die gereedskap om versoenende verskeidenheid te realiseer. Vir die Christelike kerk dui dit op die moontlikheid om 'n ruimte van versoenende verskeidenheid te skep - 'n ruimte waar eenheid nie deur verskeidenheid bedreig word nie en die een nie die Ander vrees nie.

\section{Erkenning \\ Mededingende belange}

Die outeur verklaar dat sy geen finansiële of persoonlike verbintenis het met enige party wat haar nadelig kon beïnvloed in die skryf van hierdie artikel.

\section{Literatuurverwysings}

Anderson, D. (ed.), 1980, St. Basil the Great on the Holy Spirit, St. Vladimir's Seminary Press, Crestwood, NY.

Asmus, R., 1910, 'Die Invektiven das Gregorius von Nazianz im Lichte des Werke Kaisers Julián', Zeitschrift für Kirchengeschichte 31, 325-367.

Assmann, A., 1993 Die Arbeit am nationalen Gedächtenis: Eine kurze Geschichte der deutschen Bildungsidee, Campus Verlag, Frankurt am Main.

Assmann, A., 2012a, Cultural memory and Western civilization: Functions, media, archives, Cambridge University Press, Cambridge.

Assmann, A., 2012b, Auf dem Weg zu einer europäischen Gedächtniskultur? , Picus Verlag, Wien. (Wiener Vorlesungen im Rathaus, vol. 161).

Athanasius Alexandrinus [A.D. 4] 'De sancta trinitate', in C. Bizer, 1970, 'Studien zu pseudathanasiiatischen Dialogen der Orthodoxos und Aëtios', Rheinische Friedrich-Wilhelm Universität, Bonn.

Badiou, A., [2005] 2007, The century, transl. A. Toscano, Polity, Cambridge. PMCid:PMC1855455

Barth, K., [1924] 1925, Das Wort Gottes und die Theologie: Gesammelte Vorträge, Chr. Kaiser Verlag, München.

Barnes, M.R., 2001, The power of God. Dūnamis in Gregory of Nyssa's Trinitarian Theology, Catholic University of America Press, Washington, DC.

Beeley, C.A., 2008, Gregory of Nazianzus on the Trinity and the knowledge of God: In your light we shall see light, Oxford University Press, Oxford. (Oxford Studies in Historical Theology). http://dx.doi.org/10.1093/acprof:o so/9780195313970.001.0001

Bethune-Baker, F., 1903, 'Tertullian's use of substantia, natura, and persona', Journal of Theological Studies 4, 440-442. http://dx.doi.org/10.1093/jts/os-IV.15.440

Børtnes, J. \& Hägg, T., 2006, Gregory of Naziansus: Images and reflections, Tuscalanum, Copenhagen.

Bryant, M.D., 1990, 'Recovering the trinitarian foundations of Christian experience: A pathway to Christian unity', Dialogue \& Alliance 4(3), 4-20.

Callen, B.L., 2004, Discerning the divine: God in Christian theology, Westminister John Knox, Louisville, KY.

Calvyn, J., [1559] [1931] 1956, Johannes Calvijn Institutie of onferwijzing in de christelkike godsdienst, eerste deel, bevattende boek I en II, uit Latyn vertaald door A. Sizoo, vijfde druk, W.D. Meinema N.V., Delft.

Coakley, S. (ed.), 2003, Re-thinking Gregory of Nyssa, Blackwell, Oxford.

Cox, H., 1999, 'The myth of the twentieth century: The rise and fall of "secularization", in G. Baum (ed.), The twentieth century: A theological overview, pp. 135-143, Orbis Books, Maryknol, NY.

Cunningham, D.S., 2003, 'The Trinity', in K.J. Vanhoozer (ed.), The Cambridge companion to postmodern theology, pp. 186-202, Cambridge University Press, Cambridge http://dx.doi.org/10.1017/CCOL052179062X.011

Daley, B.E., 2003, 'Gregory of Nazianzus', in S. Coakley (ed.), Rethinking Gregory of Nyssa, pp. 432-426, Routledge, New York. (Early Church Fathers Series). PMid:12635972

De Witt, F.J., 2008, 'Church and Trinity: Implications for a contemporary ecclesiology', MA thesis, Department of Dogmatics, Faculty of Theology, University of the Free State.

Dienst, K., 2012, 'Kirche mitten in der Stadt! Willy Borngässer (1905-1965): Ein Liberaler Pfarrer zwischen den Fronten', Journal of Religious Culture/Journal für Religionskultur 154, 1-172.

Dionisius Romanus [A.D. 3], 'Epistula ad Dionysium Alexandrinum', in C.L. Feltoe (ed.), 1904, The letters and other remains of Dionysius of Alexandria, pp. 176-182, Cambridge University Press, Cambridge.

Elm, S., 2012, Sons of Hellenism, fathers of the church: Emperor Julian, Gregory of Nazianzus, and the vision of Rome, University of California Press, Berkeley. PMCid:PMC3424355

Engelbrecht, B.J., 1978, 'Enkele dogmatiese opmerkings oor die kerklike leer aangaande die Triniteit, met besondere verwysing na die status van die preen posteksistente Christus ten opsigte van die Vader', in J.P. Oberholzer (red.), Teologie in die kerk, bl. 136-187, HAUM, Pretoria.

Feuerbach, L., [1841] 1853] 2008, Essence of Christianity, transl. G. Eliot, Cosimo, New York, NY.

Fiddes, P.S., 2000, Participating in God: A pastoral doctrine of the Trinity, Darton, Longman \& Todd, London.

Grenz, S.J., 2001, The social God and the relational self: A Trinitarian theology of the imago Dei, Westminster John Knox Press, Louisville, CT.

Habermas, J., [1998] 2001, The postnational constellation: Political essays, transl. M. Pensky, Polity Press, Cambridge.

Hildebrand, S.M., 2007, The Trinitarian theology of Basil of Caesarea: A synthesis of Greek thought and biblical truth, Cambridge University Press, Cambridge.

Jaeger, W. (red.), 1960, 'Contra Eunomium libri', in Gregorii Nysseni Opera 1-2, 2nd edn., pp. 127-141,Brill, Leiden.

Jenson, R., 1982, The triune identity, Fortress, Philadelphia, PA. PMCid:PMC1916006

Karfikova, L., Douglass, S. \& Zachhuber, J. (eds.), 2007, Gregory of Nyssa: Contra Eunomium II, an English version with supporting studies, proceedings of the 10th international colloquium on Gregory of Nyssa, Brill, Leiden. 
Kärkkäinen, V.-M., 2004, The doctrine of God: A global introduction, Baker Academic, Grand Rapids, MI.

Kasper, W., 1984, The God of Jesus Christ, Crossraod, New York, NY. PMCid:PMC263510

Kearney, R., 2010, Anatheism: Returning to God after God, Columbia University Press, New York, NY.

Kelly, L.G., 2002, Grammar: Theology, philosophy and the modistae, John Benjamins Publishing, Philadelphia, PA. (Studies in the History of Language Series).

Koch, A.M., 2009, 'Book review of The Century by Alain Badiou', The Philosophy of the Social Sciences 39, 119-122, viewed 1 January 2013, from http://dx.doi. org/10.1177/0048393108328142

Körtner, U.H.J., 2010, 'Kirche und Gemeinde in Zeiten des Umbruchs: Systematischtheologische Reflexionen', Evangelische Theologie 70(6), 416-426.

Lossky, V., 1957, The mystical theology of the Eastern Church, James Clark Publishing, Cambridge.

Ludlow, M., 2007, Gregory of Nyssa: Ancient and (post-)modern, Oxford University Press, Oxford. http://dx.doi.org/10.1093/acprof:oso/9780199280766.001.0001

Luz, U., 2010, 'Ortsgemeinde und Gemeinschaft im Neuen Testament', Evangelische Theologie 70(6), 404-415.

Mannion, G., 2007, Ecclesiology and postmodernity: Questions for the church in our time, Liturgical Press, Collegeville, MN.

Mariña, J. (ed.), 2005, The Cambridge companion to Friedrich Schleiermacher, Cambridge University Press, Cambridge. http://dx.doi.org/10.1017/ CCOL0521814480

Maspero, G.G., 'Remarks on the relevance of Gregory of Nyssa's Trinitarian doctrine for the epistemological perspective of 20th century psychoanalysis', European Journal of Science and Theology 6(1), 17-31.

McGuckin, J.A., 2001a, Gregory of Nazianzus: An intellectual biography, St. Vladimir's Seminary Press, Crestwood, NY.

McGuckin, J.A., 2001b, Standing in God's holy fire: The Byzantine tradition, Orbis Books, New York, NY.

Meijering, E.P. \& Van Winden, J.C.M., 1982, Hilary of Poitiers on the Trinity: De Trinitate I, Brill, Leiden.

Meyendorff, J., 1974, Byzantine theology: Historical trends and doctrinal themes, Fordham University Press, New York, NY.

Migliore, D.L., 2004, 'The communion of the Triune God: Towards a Trinitarian ecclesiology in Reformed perspective', in W.M. Alston \& M. Welker (eds.), Reformed theology: Identity and ecumenicity, pp. 140-154, Eerdmans, Grand Rapids, MI.

Mitchell, S., 1993, Anatolia: Land, men and gods in Asia Minor, 2 vols., Oxford, Clarendon Press

Mitchell, M.M. \& Young, F.M., 2006, Cambridge history of Christianity, vol. 1, Origins to Constantine, Cambridge University Press, Cambridge.

Möhler, J.A., [1872] 1996, Unity in the church or the principle of catholocism: Presented in the spirit of the church fathers of the first three centuries, transl. P. Erb, Catholic in the spirit of the church fathers of the first three centuries, trans.
University of America Press, Washington, DC. PMCid:PMC38007

Moltmann, J., [1980] 1981, The Trinity and the kingdom: The doctrine of God, transl. M. Kohl, SCM Press, London.

Moreschini, C. \& Norelli, E., 2005a, Early Christian Greek and Latin literature: A literary history, vol. 1, From Paul to the age of Constantine, transl. M.J. O'Connell, Hendrickson, Peabody, MA.

Moreschini, C. \& Norelli, E., 2005b, Early Christian Greek and Latin literature: A literary history, vol. 2, From the Council of Nicea to the beginning of the Medieval period, transl. M.J. O'Connell, Hendrickson, Peabody, MA.

Muhrmann-Kahl, M., 1997, Mysterium Trinitatis, Walter de Gruyter, Berlin.

Naudé, P., 2007, 'Daar is net een God', in R. Nel \& H. du Toit (eds.), Pilgrimage to unity: Conversations on healing and reconciliation within the Dutch Reformed Church family, pp. 1-8, viewed 02 January 2013, from http://www.gemeentes.co.za/Pdf/ Daar_een_God.pdf

Niebuhr, R., 1964, Schleiermacher on Christ and Religion: A new introduction, Charles Scribner's Sons, New York.

O'Collins, G., 1999, The Holy Trinity: The state of the question', in S.T. Davis, D. Kendall $\& \mathrm{G}$. O'Collins (eds.), The Trinity: An interdisciplinary symposium on the Trinity, pp. 1-25, Oxford University Press, Oxford.
O'Donnell. J., 1988, 'The Trinity as divine community: A critical reflection upon recent theological developments', Gregorianum 69(1), 5-34.

Pannenberg, W., 1991, Systematic theology, Eerdmans, Grand Rapids, MI.

Rousseau, P., 1994, Basil of Caesarea, The transformation of the classical heritage 20, University of California Press, Berkeley, CA.

Rush, W.G., 1980, The Trinitarian controversy, Fortress, Philadelphia, PA. PMCid:PMC1704990

Sartre, M., [2001] 2005, The Middle East under Rome, transl. C. Porter, E. Rawlings \& J. Roitier-Pucci, Harvard University Press, Cambridge, MA. PMid:16173014

Schaff, P., 1977, Bibliotheca symbolica ecclesiae universalis: The creeds of Christendom, with a history and critical notes, vol. 3, Harvard, Cambridge, MA.

Schleiermacher, F.D.E., [1830] 1928, The Christian faith, transl. of 2nd edn. H.R. Mackintosh \& J.S. Stewart, T\&T Clark, Edinburgh.

Schleiermacher, F.D.E. [1822] 1835, 'On the discrepancy between the Sabellian and Athanasian method on representing the doctrine of the Trinity', transl. M. Stuart, Biblical Repository and Quarterley Observer, April, 5-6; July, 31-35.

Schleiermacher, F.D.E. [1832] 1864, Jesu: Vorlesungen an der Universität zu Berlin im Jahr 1832, ed. K. Rütenik, Reimer Verlag, Berlin.

Schüssler Fiorenza, F., 2005, 'Schleiermacher's understanding of God as triune', in J. Mariña (ed.), The Cambridge companion to Friedrich Schleiermacher, pp. 171-188, Cambridge University Press, Cambridge. http://dx.doi.org/10.1017/ CCOL0521814480.010

Shults, F.R., 2005, Reforming the doctrine of God, Eerdmans, Grand Rapids, MI. PMCid:PMC2361767

Shults, F.R., 2006, 'Trinitarian faith-seeking transformative understanding', in 0 . Clayton \& Z. Simpson (eds.), The Oxford handbook of religion and science pp. 488-502, Oxford University Press, Oxford. http://dx.doi.org/10.1093/ oxfordhb/9780199279272.003.0030

Silvas, A.M., 2007, Gregory of Nyssa: The letters, introduction, translation and commentary, Brill, Leiden. http://dx.doi.org/10.1163/ej.9789004152908.i-283

Smit, D.J., 2006, 'Church unity in freedom', in M. Volf \& M. Welker (eds.), God's life in Trinity, pp. 73-92, Fortress, Minneapolis, MN.

Tertullian [1985], Adversus Praxean, ed. \& transl. G. Scarput, Società Editrice Internazionale, Turin

Torrance, A.C., 2012, Penitence in late Antiquity: Eastern asceticism and the framing of the Christian life c.400-650 CE, Oxford University Press, Oxford.

Turcescu, L., 2005, Gregory of Nyssa and the concept of divine persons, Oxford University Press, Oxford. http://dx.doi.org/10.1093/0195174259.001.0001

Vaggione, R.P., 2000, Eunomius of Cyzicus and the Nicene revolution, Oxford University Press, Oxford.

Van Dam, R., 2002, Kingdom of snow: Roman rule and Greek culture in Cappadocia, University of Pennsylvania Press, Philadelphia, PA.

Van den Brink, B., 1940, De Nederlandsche Belijdenisschriften, Uitgevers-maatschappij Holland, Amsterdam

Venter, R., 2004, 'Trinitariese verbeelding en post-apartheid Suider-Afrika: Fragmente oor dogmatisering en dosering', Acta Theologica Supplementum 6, 207-239.

Venter, R., 2006, 'Space, Trinity and city: A theological exploration', Acta Theologica 26(1), 201-224.

Venter, R., 2011, Speaking God today: The adventures of a rediscovered Trinitarian grammar, inaugural lecture, University of the Free State, SUN Media, University of the Free State, Bloemfontein.

Von Geoffrey, H. \& Assmann, A., 2012, Die Zukunft der Erinnerung und der Holocaust, Konstanz University Press, Konstanz.

Von Harnack, A., 1888 Lehrbuch der Dogmengeschichte, Band II: Die Entwickelung des christlichen Dogmas, Mohr Siebeck, Tübingen.

Weber, O., [1963] 1967a, 'Berufung und Hoffnung des Menschen in der Gemeinde', in Karl Barths Kirchliche Dogmatik: Eine einführender Bericht zu den Bänden I,1 bis IV, 3, 2, pp. 310-330, 6. Auflage, Neukirchener Verlag, Neukirchen-Vluyn.

Weber, O., [1963] 1967b, 'Der dreienige Gott', in Karl Barths Kirchliche Dogmatik: Eine einführender Bericht zu den Bänden I, 1 bis IV, 3, 2, pp. 11-21, 6. Auflage, Neukirchener Verlag, Neukirchen-Vluyn.

Wiles, M.F. \& Yarnold, E.J., 2011, Dia Patristica: Historica, biblica, theologica et philosophica, Peeters Publishers, Leuven.

Young, F.M., \& Teal, A., [1983] 2010, From Nicaea to Chalcedon: A guide to the literature and its background, second edition, SCM Press, London. 